\title{
Produksi Benit Kentang Secara Aeroponik dengan Root Zone Cooling di Dataran Rendah Tropika Basah dan APLIKASI BIOPESTISIDA
}

(Potatoes Seed Production in the aeroponics system with root zone cooling and biopesticides application in wet tropical lowland)

\author{
Eni Sumarni ${ }^{1}$, Noor Farid $^{2}$, Jajang Juansah ${ }^{3)}$, L Soesanto ${ }^{4)}$ \\ 1)Jurusan Teknologi Pertanian, Program Studi Teknik Pertanian, Universitas Jenderal Soedirman \\ ${ }^{2)}$ Jurusan Agroteknologi, Fakultas Pertanian, Universitas Jenderal Soedirman \\ ${ }^{3)}$ Departemen Fisika, Fakultas Matematika dan Ilmu Pengetahuan Alam, Institut Pertanian Bogor \\ ${ }^{4} J u r u s a n$ Hama dan Penyakit Tanaman, Fakultas Pertanian, Universitas Jenderal Soedirman \\ Jl. dr. Suparno, Karangwangkal, Purwokerto, 532123
}

\begin{abstract}
ABSTRAK
Teknologi aeroponik untuk dataran rendah tropika basah telah dikembangkan dengan aplikasi root zone cooling (RZT). Suhu udara yang tinggi di dataran rendah memicu penyakit. Biopestisida telah diuji untuk bawang merah, tomat, kacang tanah dan cabe di Banyumas, tetapi belum diketahui bagaimana pengaruhnya apabila diaplikasikan pada sistem aeroponik dengan RZT di dataran rendah. Tujuan penelitian yaitu mendapatkan konsentrasi biopestida untuk pertumbuhan dan hasil terbaik dari varietas yang ditanam secara aeroponik dengan RZT di dataran rendah tropika basah. Faktor yang dicoba meliputi: box aeroponik tanpa RZT, biopestisida $1 \mathrm{ml} /$ liter (B1), box aeroponik RZT $10^{\circ} \mathrm{C}$, biopestisida $4 \mathrm{ml} /$ iter (B2), box aeroponik $\mathrm{RZT} 10^{\circ} \mathrm{C}$, tanpa biopestisida (B3), box aeroponik RZT $10^{\circ} \mathrm{C}$, biopestisida $10 \mathrm{ml} /$ liter (B4) dan varietas bibit kentang: Varietas Alantic (V1), Varietas Granola (V2). Penelitian menggunakan rancangan acak lengkap (RAL) dan diulang sebanyak 4 kali. Analisis data menggunakan sidik ragam dilanjutkan DMRT pada taraf $\alpha=$ $5 \%$. Hasil menunjukkan bahwa varietas granola pada sistem aeroponik dengan RZT dan aplikasi biopestisida $4 \mathrm{ml} /$ liter dan $10 \mathrm{ml} /$ liter memberikan tinggi tanaman tertinggi. Biopestisida $10 \mathrm{ml} /$ liter menghasilkan rata-rata jumlah daun tertinggi, dan biopestisida $4 \mathrm{ml} /$ liter menghasilkan jumlah umbi tertinggi.
\end{abstract}

Kata kunci: aeroponik, atlantic, benih kentang, dataran rendah tropika, granola, root zone cooling

\begin{abstract}
Aeroponic technology for wet tropical lowlands have been developed with the application root zone cooling (RZT). High temperatures in the lowlands trigger the disease. Biopesticides have been tested for red onions, tomatoes, peanuts and chili in Banyumas, but it is not known what effect, if applied to the aeroponic system with $R Z T$ in the lowlands. The research objective is to get the concentration biopestida for growth and the best results of the varieties grown in aeroponics to RZT in wet tropical lowlands. Factors to be tested: box aeroponic without $R Z T$ and biopesticides $1 \mathrm{ml} /$ liter (B1), box aeroponics $R Z T 10{ }^{\circ} \mathrm{C}$ biopesticides $4 \mathrm{ml} /$ liter (B2), box aeroponics $R Z T 10^{\circ} \mathrm{C}$ without biopesticides (B3), aeroponics box $R Z T 10^{\circ} \mathrm{C}$ biopesticides $10 \mathrm{ml} /$ liter (B4). The varieties of seed potatoes: Alantic varieties (V1), Variety Granola (V2). The study used a completely randomized design (CRD) and repeated 4 times. Analysis of data using analysis of variance followed by DMRT at the level of $\alpha=5 \%$. Results showed that the varieties of granola in aeroponic system with RZT and application of biopesticides $4 \mathrm{ml}$ liter and $10 \mathrm{ml}$ liter gave the highest plant height. Biopesticides $10 \mathrm{ml} /$ liter on average produces the highest number of leaves, and biopesticides $4 \mathrm{ml} /$ liter produces the highest number of tubers.
\end{abstract}

Keywords : aeroponics, atlantic, granola, potatoes seed, root zone cooling, wet tropical, lowland

Diterima : 5 September 2016; Disetujui : 19 Oktober 2016

22 Produksi Benih Kentang Secara Aeroponik dengan Root Zone Cooling di Dataran Rendah Tropika Basah dan Aplikasi Biopestisida 


\section{PENDAHULUAN}

Beberapa negara di Asia dan Eropa merupakan penghasil kentang utama di dunia. Produksi di negara-negara tersebut mencapai $80 \%$ dari produksi kentang dunia pada tahun 2007. Beberapa negara di Asia memiliki potensi produksi kentang hampir $50 \%$ dari pasokan kentang di dunia (Prakash et.al., 2010). Kentang adalah salah satu tanaman yang dapat diperbanyak secara vegetatif dari generasi ke generasi, namun umbi bibit kentang yang diperbanyak secara vegetatif berpotensi menyebarkan penyakit apabila pada tahap produksinya tidak dikontrol dengan baik.Produksi benih kentang perlu didasari bibit awal yang berkualitas tinggi, baik itu bebas dari penyakit yang terbawa saat masih berbentuk planlet, maupun bebas penyakit pada saat berbentuk umbi mini. Greenhouse atau screenhouse yang digunakan untuk produksi benih kentang umummnya masih menggunakan teknologi konvensional, yaitu dengan menggunakan tanah, gambut, dan media tanam lain tanpa sterilisasi. Sistem tersebut menunjukkan hasil produksi benih yang masih rendah, maksimal yang dapat dicapai adalah 5 umbi per tanaman, oleh karena itu memiliki resiko adanya infeksi, dan penyakit tular tanah (Rodriguezet.al., 2014; Danielsset, 2000).

Salah satu jalan keluar dari permasalahan ini adalah dengan menggunakan teknologi substrat, namun ada permasalahan yang timbul dari teknologi substrat tersebut, diantaranya adalah ketersediaan, heterogenitas, infeksi, dan kualitas bahan substrat. Teknologi alternatif untuk memproduksi benih kentang mini tanpa menggunakan tanah telah dikembangkan dengan teknologi aeroponik (Farran et.al., 2006; Christie dan Nichols, 2004; Sumarni et.al., 2014). Teknologi aeroponik untuk dataran rendah tropika basah juga telah dikembangkan dengan aplikasi root zone cooling(Sumarni et.al., 2013ab; Sumarni dan Sudarmaji, 2014). Teknologi ini mengontrol pertumbuhan dan hasil umbi melalui air yang telah berisi nutrisi, sehingga permasalahan pada teknologi substrat dapat diatasi. Teknologi aeroponik di dataran rendah dan apliaksi root zone cooling perlu terus dikuatkan agar jumlah umbidan kualitas kentang meningkat. Faktor lingkungan yang yang mempengaruhi pertumbuhan dan hasil benih kentang di dataran rendah adalah suhu udara. Suhu optimal untuk pertumbuhan umbi adalah sekitar $16{ }^{\circ} \mathrm{C}$, sementara itu di dataran rendah suhu udara di permukaan daun di dalam greenhouse dapat mencapai lebih dari $30^{\circ} \mathrm{C}$. Suhu daerah perakaran di dataran rendah dengan ketinggian $115 \mathrm{~m}$ dpl mencapai lebih dari $33{ }^{\circ} \mathrm{C}$ tanpa aplikasi root zone cooling(Sumarni dan Farid, 2014). Suhu media tanam yang tinggi dapat menunda pertumbuhan dan hasil benih kentang. Suhu udara yang tinggi di dataran rendah memicu pertumbuhan penyakit pada tanaman kentang.Penyakit yang menyerang tanaman kentang meningkat pada suhu yang ekstrim(Garcia et.al., 2006). Salah satu penyakit yang juga sering menyerang tanaman kentang pada sistem aeroponik di dataran rendah adalah penyakit layu bakteri (Sumarni dan Sudarmaji, 2014).

Petani kentang di 80 negara di dunia pernah mengalami gagal panen, dengan luas total serangan mencapai 1,5 juta ha dan kerugian mencapai US\$950 juta setiap tahun (Supriadi, 2011). Pengendalian layu bakteri dengan pestisida alami telah diupayakan. Penggunaan biopestisida tersebut dapat menekan penyakit tanaman, juga dapat mengurangi pencemaran di lahan pertanian. Biopestisida telah diuji coba pada pertanian bawang merah di Gebang, tomat di Universitas Jenderal Soedirman Kaliangkrik,serta kacang tanah dan cabe di Banyumas, tetapi belum diketahui bagaimana pengaruhnya apabila diaplikasikan pada sistem aeroponik dengan root zone cooling di dataran rendah. Keunggulan Biopestisida adalah tidak hanyamengendalikan jamur, virus, dan bakteri, namun juga menghasilkan hormon yang merangsang pertumbuhan tanaman (Soesanto, 2012). Hal ini sangat menguntungkan bagi para petani, oleh karena itu penelitian terpadu antara teknologi budidaya dan pengendalian penyakit perlu dilakukan dalam rangka mendapatkan informasi ilmiah yang lengkap dan upaya meningkatkan produksi benih kentang. Aplikasi biopestisida untuk pengendalian penyakit pada teknologi aeroponik dengan root zone cooling di 
dataran rendah tropika basah diperlukan untuk mengoptimalkan hasil benih kentang. Tujuan dari penelitian ini yaitu mendapatkan konsentrasi biopestida yang dapat memberikan pertumbuhan dan hasil terbaik dari varietas yang ditanam secara aeroponik dengan root zone cooling di dataran rendah tropika basah.

\section{METODOLOGI PENELITIAN}

Penelitian produksi benih kentang secara aeroponik dengan root zone coolingdan aplikasi biopestisida di dataran rendah tropika basah dilaksanakan di Greenhouse Fakultas Pertanian, Universitas Jenderal Soedirman. Penelitian dilaksanakan pada bulan Mei sampai dengan Agustus 2015. Ketinggian tempat penelitian adalah $115 \mathrm{~m}$ dpl. Alat-alat yang digunakan dalam penelitian meliputi EC meter untuk mengukur kepekatan larutan nutrisi pada range 1,5 sampai $1,8 \mathrm{mS} / \mathrm{cm}^{2}, \mathrm{pH}$ meter untuk mengukur asam dan basa larutan nutrisi pada posisi 6, termohygrometer untuk mendapatkan suhu dan kelembapan di dalam maupun diluar greenhouse, penggaris untuk mengukur tinggi tanaman, pompa untuk mengalirkan larutan nutrisi. Bibit kentang yang digunakan adalah planlet hasil kultur jaringan yang telah di stek. Varietas bibit kentang yang digunakan ada dua yaitu varietas Atlantic dan Granola. Bibit kentang tersebut berasal dari Balitsa, Lembang Bandung.Biopestisida yang digunakan adalah Bio P60 yang dikembangkan oleh Prof. Loekas Soesanto (Unsoed) dan telah mendapatkan hak paten KemenRistek.

Penelitian produksi benih kentang secara aeroponik dengan root zone coolingdan aplikasi biopestisidadi dataran rendah tropika basah menggunakan suhu root zone cooling $10^{\circ} \mathrm{C}$. Suhu tersebut merupakan hasil penelitian sebelumnya yang menghasilkan benih kentang dengan produktivitas tertinggi, yaitu $579 \mathrm{umbi} / 1.5 \mathrm{~m}^{2}$ pada ketinggian $250 \mathrm{~m} \mathrm{dpl}$ (Sumarni et.al., 2013a) dan $325 \mathrm{umbi} / \mathrm{m}^{2}$ pada ketinggian $115 \mathrm{~m}$ dpl (Sumarni dan Sudarmaji, 2014). Kondisi-kondisi yang diteliti meliputi:

1. Biopestisida :

- Box aeroponik 1 (tanpa root zone cooling), biopestisida $1 \mathrm{ml} /$ liter (B1)
- Box aeroponik 2 (root zone cooling $10{ }^{\circ} \mathrm{C}$ ), biopestisida $4 \mathrm{ml} /$ liter (B2)

- Box aeroponik 3 (root zone cooling $10{ }^{\circ} \mathrm{C}$ ), tanpa biopestisida (B3)

- Box aeroponik 4 (root zone cooling $10^{\circ} \mathrm{C}$ ), biopestisida $10 \mathrm{ml} /$ liter (B4)

2. Varietas bibit kentang :

- Varietas 1 : Alantic (V1)

- Varietas 2 : Granola (V2)

Larutan nutrisi yang digunakan memiliki EC : $1,5 \mathrm{mS} / \mathrm{cm}$ pada 3 minggu pertama, dan 1,8 $\mathrm{mS} / \mathrm{cm}^{2}$ sampai panen,sedangkan $\mathrm{PH}$ larutan nutrisi sebesar 6. Penelitian menggunakan rancangan acak lengkap (RAL) dan diulang sebanyak 4 kali ulangan. Analisis data menggunakan sidik ragam dan dilanjutkan dengan DMRT pada taraf $\alpha=5 \%$.

\section{HASIL DAN PEMBAHASAN}

Kondisi lingkungan selama penelitian, meliputi Ssuhu udara di dalam greenhouse berkisar 31-40 ${ }^{\circ} \mathrm{C}$,sedangkan suhu di luar greenhouse berkisar $30-36^{\circ} \mathrm{C}$, kelembaban relatif atau relatif humidity $(\mathrm{RH})$ di dalam greenhouse rata-rata sebesar $75,5 \%$, sedangkan $\mathrm{RH}$ di luar greenhouse rata-rata $80 \%$. Intensitas cahaya di dalam greenhouse pada pagi hari (pukul 8:00) mencapai 500-4750 lux, siang hari (pukul 13:00) berkisar 4550-51200 lux dan sore hari (pukul 16:00) 2005125 lux. Intensitas cahaya di luar greenhouse pada pagi hari (pukul 8:00) mencapai 700-6650 lux, siang hari (pukul 13:00) mencapai 6370-71680 lux dan sore hari (pukul 16:00) berkisar 280-7175 lux. Intensitas cahaya yang masuk ke dalam greenhouse lebih kecil dibandingkan di luar greenhouse.

Radiasi matahari yang masuk ke dalam greenhouse mempengaruhisuhu udara dalam greenhouse dan berpengaruh terhadap keseimbangan termal dalam greenhouse, sehingga menyebabkan kondisi termal yang berbeda dengan kondisi di sekitar greenhouse (Worley, 2011). Radiasi matahari merupakan faktor penting pada lingkungan greenhouse. Transmisi radiasi matahari yang masuk ke dalam greenhouse berpengaruh terhadap kondisi iklim pertumbuhan tanaman (Wang dan Boulard, 2000; Toor et al., 2006). Jumlah radiasi matahari pada suatu titik tertentu

24 Produksi Benih Kentang Secara Aeroponik dengan Root Zone Cooling di Dataran Rendah Tropika Basah dan Aplikasi Biopestisida 
adalah radiasi matahari global atau total. Kondisi tersebut dipengaruhi oleh kondisi langit (berawan atau tidak), waktu dalam satu tahun, latitude dan geometri matahari, arah orientasi bangunan (Wang dan Boulard, 2000).

\section{Pertumbuhan dan Hasil Tanaman}

Hasil analisis sidik ragam menunjukkan bahwa varietas tanaman kentang, biopestisida yang digunakan dan interaksinya berperngaruh nyata terhadap tinggi tanaman. Pemberian biopestisida juga memberikan pengaruh nyata pada pertumbuhan jumlah daun dan jumlah umbi, sedangkan varietas dan interaksi antara varietas dan biopestisida memberikan pengaruh yang tidak berbeda terhadap jumlah daun.

\section{Tinggi Tanaman Kentang}

Varietas kentang Atlantic dan Granola dengan pemberian biopestisida memberikan pertumbuhan tinggi rata-rata tanaman kentang yang berbeda-beda (Tabel 1). Varietas granola yang ditanam secara aeroponik dengan root zone cooling suhu $10{ }^{\circ} \mathrm{C}$ dan aplikasi biopestisida 4 $\mathrm{ml} /$ liter dan $10 \mathrm{ml} /$ liter memberikan pertumbuhan tinggi tanaman tertinggi dibandingkan perlakuan lainya, yaitu $34.5 \mathrm{~cm}$ dan $36.4 \mathrm{~cm}$. Pertumbuhan tinggi tanaman terendah diperoleh pada varietas atlantic dan granola yang ditanam tanpa root zone cooling dan aplikasi biopestisida $1 \mathrm{ml} /$ liter, yaitu $14.6 \mathrm{~cm}$ dan $11.7 \mathrm{~cm}$.

Tabel 1. Pengaruh perlakuan terhadap rata-rata tinggi tanaman kentang

\begin{tabular}{ccc}
\hline \multirow{2}{*}{ Perlakuan } & \multicolumn{2}{c}{ Tinggi Tanaman $(\mathbf{c m})$} \\
\cline { 2 - 3 } & $\mathbf{4 5} \mathbf{H S T}$ & $\mathbf{5 0 ~ H S T}$ \\
\hline V1B1 & $13.2 \mathrm{~d}$ & $14.6 \mathrm{c}$ \\
V1B2 & $23.1 \mathrm{~b}$ & $23.8 \mathrm{~b}$ \\
V1B3 & $16.7 \mathrm{c}$ & $22.6 \mathrm{~b}$ \\
V1B4 & $15.9 \mathrm{c}$ & $23.8 \mathrm{~b}$ \\
V2B1 & $9.75 \mathrm{e}$ & $11.7 \mathrm{c}$ \\
V2B2 & $33.2 \mathrm{a}$ & $34.5 \mathrm{a}$ \\
V2B3 & $22.3 \mathrm{~b}$ & $20.6 \mathrm{~b}$ \\
V2B4 & $21.9 \mathrm{~b}$ & $36.4 \mathrm{a}$ \\
\hline
\end{tabular}

Keterangan: Angka-angka yang diikuti huruf yang sama pada kolom yang sama menunjukkan tidak berbeda nyata berdasarkan DMRT pada taraf $\alpha=5 \%$; HST = hari setelah tanam .
Bio P60 merupakan agensia hayati yang diisolasi dari perakaran gandum (Soesanto et al., 2011) dan telah digunakan untuk pengendalian hayati patogen tulartanah(Santoso et al., 2007).Sistem penanaman aeroponik memberikan nutrisi melalui semprotan ke akar tanaman. Sistem ini diduga dapat membantu optimalisasi kerja dari Biopestisida.Prosentase tanaman tumbuh sampai 50 HST pada sistem aeroponik dengan aplikasi root zone cooling dan biopestisida $4 \mathrm{ml} /$ liter mencapai $80 \%$ dan $10 \mathrm{ml} /$ liter mencapai $78 \%$. Bibit kentang yang ditanam secara aeroponik dengan root zone cooling tanpa aplikasi biopestisida memberikan prosentase tanaman tumbuh $70 \%$ sampai umur 50 HST.

\section{Jumlah Daun dan Umbi Tanaman Kentang}

Pemberian biopestisida pada sistem aeroponik dengan root zone coolingdi dataran rendah memberikan respon yang berbeda-beda terhadap jumlah daun (Tabel 2). Biopestisida 10 $\mathrm{ml} /$ liter menghasilkan rata-rata jumlah daun tertinggi (60.2 helai), sedangkan jumlah daun terendah dihasilkan pada pemberian biopestisida 1 $\mathrm{ml} /$ liter tanpa aplikasi root zone cooling (14.9 helai).

Tabel 2. Pengaruh pemberian biopestisida terhadap rata-rata jumlah daun (helai) dan jumlah umbi per tanaman

\begin{tabular}{|c|c|c|c|}
\hline \multirow{2}{*}{ Perlakuan } & \multicolumn{2}{|c|}{ Jumlah Daun (helai) } & \multirow{2}{*}{$\begin{array}{c}\text { Jumlah } \\
\text { Umbi/tanaman }\end{array}$} \\
\hline & 45 HST & 50 HST & \\
\hline B1 & $11.2 \mathrm{c}$ & $14.9 \mathrm{c}$ & $1.1 \mathrm{c}$ \\
\hline B2 & $58.1 \mathrm{a}$ & $60.2 \mathrm{a}$ & $4.3 \mathrm{a}$ \\
\hline B3 & $20.6 \mathrm{~b}$ & $20.7 b$ & $1.0 \mathrm{c}$ \\
\hline B4 & $21.6 \mathrm{~b}$ & $30.1 \mathrm{~b}$ & $2.6 \mathrm{~b}$ \\
\hline
\end{tabular}

Keterangan: Angka-angka yang diikuti huruf yang sama pada kolom yang sama menunjukkan tidak berbeda nyata berdasarkan DMRT pada taraf $\alpha=5 \%$; HST = hari setelah tanam.

Parameter Parameter pertumbuhan yang dapat mempengaruhi parameter lainya adalah jumlah daun. Jumlah daun dapat berpengaruh terhadap jumlah umbi yang dihasilkan (Salisburry dan Ross, 1995). Hasil uji lanjut DMRT menunjukkan bahwa jumlah daun yang tinggi berpotensi terhadap jumlah umbi yang tinggi. 
Aplikasi biopestisida sebanyak $4 \quad \mathrm{ml} /$ liter menghasilkan jumlah umbi tertinggi sebanyak 4.3 umbi pertanaman, sedangkan jumlah umbi terendah diperoleh pada aplikasi biopestisda 1 $\mathrm{ml} /$ liter dan tanpa biopestisida.

\section{KESIMPULAN}

Varietas granola yang ditanam secara aeroponik dengan root zone cooling suhu $10{ }^{\circ} \mathrm{C}$ dan aplikasi biopestisida $4 \mathrm{ml} /$ liter dan $10 \mathrm{ml} /$ liter memberikan tinggi tanaman tertinggi dibandingkan perlakuan lainya, yaitu $34.5 \mathrm{~cm}$ dan $36.4 \mathrm{~cm}$. Tinggi tanaman terendah diperoleh pada varietas atlantic dan granola yang ditanam tanpa root zone cooling dan aplikasi biopestisida $1 \mathrm{ml} /$ liter, yaitu $14.6 \mathrm{~cm}$ dan $11.7 \mathrm{~cm}$. Pemberian biopestisida pada sistem aeroponik dengan root zone cooling di dataran rendah memberikan respon yang berbeda-beda terhadap jumlah daun. Biopestisida $10 \mathrm{ml} /$ liter menghasilkan rata-rata jumlah daun tertinggi $(60.2$ helai), sedangkan jumlah daun terendah dihasilkan pada pemberian biopestisida $1 \mathrm{ml} /$ liter tanpa aplikasi root zone cooling (14.9 helai). Biopestisida $4 \mathrm{ml} /$ liter menghasilkan jumlah umbi tertinggi sebanyak 4.3 umbi pertanaman, sedangkan terendah diperoleh pada biopestisda $1 \mathrm{ml} /$ liter dan tanpa biopestisida.

\section{UCAPAN TERIMA KASIH}

Uapan terima kasih disampaikan kepada KemenristekDikti melalui pendanaan skim Hibah Strategis Nasional tahun 2015, sehingga penelitian ini dapat dilaksanakan. Terima kasih juga disampaikan kepada Fakultas Pertanian atas sarana greenhouse untuk penelitian ini serta Jurusan Hama dan Penyakit Tanaman atas penggunaan biopestisida, sehingga aplikasinya dapat dilakukan pada sistem aeroponik dengan root zone cooling di dataran rendah tropika basah.

\section{DAFTAR PUSTAKA}

Agrios, N. G. 2005. Plant Pathology Fifth Edition. Departemen of Plant Pathology. University of Florida. United States of America.

Daniels, J.; Pereira, A.; Fortes, G.R.L. Verticalização da Produção de Batata-Semente por Produtores de Agricultura Familiar no Rio Grande do Sul; Embrapa Clima Temperado: Pelotas, Brasil, 2000; p. 4.

Rodriguez, J.F.M., S.D. Haan, A.R. Delfin. 2014. Genotype by Environment Effects on Potato Mini-Tuber Seed Production in an Aeroponics
System. Agronomy. 4:514-528. www.mdpi.com/journal/agronomy.

Santoso SE, Soesanto L, \& Haryanto TAD. 2007. Penekanan hayati penyakit moler pada bawang merah dengan Trichoderma harzianum, Trichoderma koningii dan Pseudomonas flourescensP60. J. HPT Tropika.7(1): 53-61.

Soesanto L, Mugiastuti E, \& Rahayuniati RF. 2011. Biochemichal characteristic of Pseudomonas flourescensP60. J. Biotechnol. and Biodiver.2:19-26.

Sumarni, E., H. Suhardiyanto, K.B. Seminar, S.K. Saptomo. 2013a. Aplikasi Pendinginan Zona Perakaran (Root Zone Cooling) pada Produksi Benih Kentang Menggunakan Aeroponik di Dataran Rendah Tropika Basah. Jurnal Agronomi Indonesia. Terakreditasi A. Vol. 41. No. 2. Agustus.

Sumarni, E., H. Suhardiyanto, K.B. Seminar, S.K. Saptomo. 2013b. Perpindahan Panas pada Aeroponik Chamber dengan Aplikasi Zone Cooling. Jurnal Biofisika. Vol 9. NO. 1. Maret. ISSN 1829-6009. FMIPA. Bogor.

Sumarni dan A. Sudarmaji. 2014. Aplikasi root zone cooling dan pengendalian lingkungan termal greenhouse pada sistem aeroponik untuk produksi benih kentang dataran rendah tropika basah. Laporan Hibah Bersaing. 70 halaman.

Sumarni, E., Ardiansyah, N. Farid. 2014. Aplikasi nozzel pada dua varietas kentang untuk produksi benih secara aeroponik. Jurnal Biofisika. 10:17.

Sumarni, E., N. Farid. 2014. Respon suhu daun pada pertumbuhan dan hasil kailan teknik aeroponik dengan aplikasi root zone cooling. Seminar Nasional. FTIP Unpad-Perteta-Hipi. Jatinangor, $11-12$ November.

Toor, R.K., G.P. Savage, and C.E. Lister. 2006. Seasonal Variation in The Antioxidant of Greenhouse Grown Tomatoes. Journal of Food Composition and Analysis. (19):1-10.

Wang,. S., and T. Boulard., 2000.. Measurement and Prediction of Solar Radiation Distribution in Full-Scale Greenhouse Tunnels. Journal Agronomie:(20)41-50.

Worley, J. 2011. Greenhouses. Heating,cooling and ventilation. Buletin 792. The University of Geeorgia. Hal:1-12. 